\title{
Demographics of paediatric renal replacement therapy in Europe: 2007 annual report of the ESPN/ERA-EDTA registry
}

\author{
Karlijn J. van Stralen • E. Jane Tizard • \\ Enrico Verrina $\cdot$ Franz Schaefer $\cdot$ Kitty J. Jager • \\ on behalf of the European Society for Paediatric \\ Nephrology/European Renal Association-European \\ Dialysis and Transplant Association \\ (ESPN/ERA-EDTA) registry study group
}

Received: 5 November 2009 /Revised: 8 January 2010 / Accepted: 12 January 2010 /Published online: 23 February 2010

(C) The Author(s) 2010. This article is published with open access at Springerlink.com

\section{The ESPN/ERA-EDTA registry}

Few data are available regarding the epidemiology of endstage renal disease (ESRD) in children. The European Society of Paediatric Nephrology (ESPN), in collaboration with the European Renal Association-European Dialysis

The ESPN/ERA-EDTA registry study group consists of: J.W. Groothoff, M.A. Lewis, P. Cochat, R. Coppo, D. Haffner, P. Niaudet, R. Kramer, R. Oberbauer, D. Batinić, Z. Puretić, Z. Mustapić, T. Seeman, K. Vondrak, J. Heaf, U. Toots, M. Ots, I. Vainumäe, P. Finne, C. Grönhagen-Riska, C. Holmberg, C. Couchoud, L. le Mignot, E. Sahpazova, G.A. Ioannidis, D. Stefanidis, G. Reusz, S. Túri, L. Szabó, T. Szabó, Z.S. Györke, E. Kis, R. Palsson, V. Edvardsson, S. Varriale, V. Strazdins, I. Andersone, A. Jankauskiene, S. Pavićević, T. Leivestad, A. Zurowska, I. Zagozdzon, C. Mota, M. Almeida, C. Afonso, G. Mircescu, L. Garneata, M. Gafencu, E. Podgoreanu, E.A. Molchanova, N.A. Tomilina, B.T. Bikbov,

A. Peco-Antic, M. Kostic, B. Spasojevic-Dimitrijeva, D. Paripovic, L. Podracka, D. Kolvek, J. Buturovic-Ponikvar, G. Novljan, R.B. Kenda, A. Alonso, P. Castro de la Nuez, J.M. Muňoz Terol, Registro de Insuficiencia Renal Crónica en Tratamiento Sustitutivo de Aragon, Á. Magaz, J. Aranzabal, I. Lampreabe, J. Arrieta, E. Arcos, J. Comas, R. Deulofeu,

J. Twose, O. Zurriaga, M. Ferrer, S. Schön, K.G. Prütz, A. Seeberger,

L. Backmän, M. Herthelius, A. Hoitsma, A. Hemke, W.F. Tromp.

K. J. van Stralen $(\bowtie)$

ESPN/ERA-EDTA registry,

Department of Medical Informatics-J1b,

Academic Medical Center, University of Amsterdam,

PO Box 22700, 1100 DE Amsterdam, The Netherlands

e-mail: k.j.vanStralen@amc.uva.nl

\section{E. J. Tizard}

Department of Paediatric Nephrology,

Bristol Royal Hospital for Children, Bristol, UK

E. Verrina

Nephrology, Dialysis and Transplantation Unit,

G. Gaslini Institute, Genoa, Italy and Transplant Association (ERA-EDTA), has recently established a meta-registry of European paediatric patient registries [1]. Thirty European countries reported individual patient data with information on date of birth, gender, start date renal replacement therapy (RRT), treatment modality at the start, changes in treatment, and important events such as

F. Schaefer

Division of Pediatric Nephrology,

Center for Pediatrics and Adolescent Medicine,

Heidelberg, Germany

K. J. Jager

ERA-EDTA registry, Department of Medical Informatics-J1b,

Academic Medical Center, University of Amsterdam, PO Box 22700, 1100 DE Amsterdam,

The Netherlands 
death and transfer out of registry. Here we provide the first demographic information obtained by the ESPN/ERA-EDTA registry, relating to the calendar year 2007, including data from 28 countries.

Hungary provided data for $86 \%$, and Russia for $50 \%$ of the population; the demographic figures from these countries were extrapolated accordingly. As Italy only provided information on those starting on dialysis, this country was omitted from the calculation of the transplantation-specific incidence and prevalence. As the majority of countries (Belarus, Croatia, Czech Republic, Estonia, FYR of Macedonia, Hungary, Italy, Latvia, Lithuania, Montenegro, Poland, Portugal, Russia, Serbia, Slovakia, Slovenia, and the United Kingdom) collected information mainly from paediatric centres, information on individuals $15-17$ years could be incomplete. In order to provide a valid comparison between countries, reporting has therefore been restricted to patients younger than 15 years of age.

Incidence was defined as the number of new patients starting RRT in 2007, and the point prevalence was given by the total number of patients on RRT on 31 December 2007 [2]. Both incidence and prevalence were expressed in absolute numbers and per million age-related population (pmarp). Furthermore, to allow calculations of the number of children on RRT based on population data, results were also expressed per million total population, including adults (pmtp).

\section{Incidence of paediatric RRT across Europe}

In 2007, the overall incidence rate of RRT among children under the age of 15 was 6.5 pmarp, which was 1.0 pmtp. The median reported incidence by region/country was 6.5 pmarp (interquartile range 3.7-7.8). The incidence was highest in adolescence (8.0 pmarp; age group 10-14 years), lowest in mid-childhood (4.6 pmarp), and intermediate (6.7 pmarp) in children younger than 5 years of age. RRT incidence was almost $50 \%$ higher in males ( 7.5 pmarp) than in females (5.4 pmarp). The modality-specific incidences were 2.8 pmarp for peritoneal dialysis, 2.4 pmarp for haemodialysis, 1.0 pmarp for pre-emptive transplantation and unknown for 0.3 pmarp (Table 1).

\section{Prevalence of paediatric RRT across Europe}

The overall point prevalence of paediatric RRT on 31 December 2007 was 33.6 pmarp, which was 5.4 pmtp. The median prevalence across countries and regions was 31.1 pmarp, with an interquartile range of 24.5 to 41.6 pmarp. Prevalence increased more than threefold from the infant to
Table 1 Incidence of paediatric patients accepted for renal replacement therapy (RRT) in 2007 and general population characteristics of countries contributing 2007 data to the European Society for Paediatric Nephrology/European Renal Association-European Dialysis and Transplant Association (ESPN/ERA-EDTA) registry

\begin{tabular}{|c|c|c|c|}
\hline \multirow[t]{3}{*}{ Country } & \multicolumn{2}{|c|}{ RRT patients } & \multirow{3}{*}{$\begin{array}{l}\text { General population } \\
0-14 \text { years } \\
\text { Count }\end{array}$} \\
\hline & \multicolumn{2}{|c|}{$0-14$ years } & \\
\hline & Count & pmarp & \\
\hline Austria & 10 & 7.7 & $1,296,776$ \\
\hline Belarus & 10 & 7.0 & $1,421,557$ \\
\hline Croatia & 2 & 2.9 & 686,967 \\
\hline Czech Republic & 9 & 6.1 & $1,478,219$ \\
\hline Denmark & 5 & 4.9 & $1,025,793$ \\
\hline Estonia & 0 & 0.0 & 199,223 \\
\hline Finland & 11 & 12.3 & 897,885 \\
\hline France & 77 & 6.5 & $11,767,559$ \\
\hline FYR of Macedonia & 3 & 7.9 & 381,868 \\
\hline Greece & 13 & 8.1 & $1,598,665$ \\
\hline Hungary $^{\mathrm{a}}$ & 3 & 2.3 & $1,306,536$ \\
\hline Iceland & 1 & 15.2 & 65,633 \\
\hline Italy $^{\mathrm{b}}$ & 35 & 4.2 & $8,350,585$ \\
\hline Latvia $^{\mathrm{c}}$ & 1 & 3.2 & 315,386 \\
\hline Lithuania & 3 & 5.7 & 527,561 \\
\hline Montenegro & 0 & 0 & 123,048 \\
\hline The Netherlands & 22 & 7.5 & $2,947,170$ \\
\hline Norway & 3 & 3.3 & 906,655 \\
\hline Poland & 41 & 6.9 & $5,961,618$ \\
\hline Portugal $^{\mathrm{c}}$ & 16 & 9.8 & $1,633,245$ \\
\hline Romania & 8 & 2.4 & $3,298,815$ \\
\hline Russia $^{\mathrm{a}}$ & 81 & 7.8 & $10,426,340$ \\
\hline Serbia & 5 & 4.4 & $1,142,760$ \\
\hline Slovakia & 4 & 4.6 & 860,833 \\
\hline Slovenia & 2 & 7.1 & 281,081 \\
\hline Spain, Andalusia & 10 & 7.6 & $1,316,682$ \\
\hline Spain, Aragon & 2 & 11.7 & 170,569 \\
\hline Spain, Basque & 1 & 3.7 & 271,786 \\
\hline Spain, Catalonia & 4 & 3.8 & $1,046,915$ \\
\hline Spain, Valencia & 7 & 9.9 & 707,577 \\
\hline Sweden & 11 & 7.1 & $1,545,660$ \\
\hline United Kingdom & 83 & 7.7 & $10,721,100$ \\
\hline Total & 483 & 6.5 & $74,682,067$ \\
\hline
\end{tabular}

Incident rates may vary over the years due to random variation because of small numbers

${ }^{a}$ Assuming $86 \%$ coverage of general population for Hungary and $50 \%$ coverage for Russia

b Pre-emptive transplantation not included

c Only patients from paediatric centres included 
Table 2 Prevalence of paediatric patients on renal replacement therapy (RRT) on 31 December 2007. Prevalent counts and prevalence per million age-related population by age and gender in countries contributing 2007 data to the European Society for Paediatric Nephrology/European Renal Association-European Dialysis and Transplant Association (ESPN/ERA-EDTA) data registry

\begin{tabular}{|c|c|c|c|c|c|c|c|c|c|c|}
\hline \multirow[t]{4}{*}{ Country } & \multirow{2}{*}{\multicolumn{2}{|c|}{$\frac{\text { Total (years) }}{\text { RRT patients }}$}} & \multicolumn{3}{|c|}{ Age groups (years) } & \multicolumn{2}{|c|}{ Gender (years) } & \multicolumn{3}{|c|}{ Treatment modality $^{\mathrm{d}}$ (years) } \\
\hline & & & \multirow{3}{*}{$\begin{array}{l}0-4 \\
\text { pmarp }\end{array}$} & \multirow{3}{*}{$\begin{array}{l}5-9 \\
\text { pmarp }\end{array}$} & \multirow{3}{*}{$\begin{array}{l}10-14 \\
\text { pmarp }\end{array}$} & \multirow{3}{*}{$\begin{array}{l}\text { Males } \\
0-14 \\
\text { pmarp }\end{array}$} & \multirow{3}{*}{$\begin{array}{l}\text { Females } \\
0-14 \\
\text { pmarp }\end{array}$} & \multirow{3}{*}{$\begin{array}{l}\text { HD } \\
0-14 \\
\text { pmarp }\end{array}$} & \multirow{3}{*}{$\begin{array}{l}\text { PD } \\
0-14 \\
\text { pmarp }\end{array}$} & \multirow{3}{*}{$\begin{array}{l}\text { Tx } \\
0-14 \\
\text { pmarp }\end{array}$} \\
\hline & $0-14$ & & & & & & & & & \\
\hline & Count & pmarp & & & & & & & & \\
\hline Austria & 54 & 41.6 & 17.5 & 50.3 & 54.3 & 49.6 & 33.3 & 2.3 & 3.9 & 35.5 \\
\hline Belarus & 19 & 13.3 & 8.7 & 17.6 & 13.4 & 13.6 & 12.9 & 2.8 & 9.8 & 0.7 \\
\hline Croatia & 19 & 27.7 & 14.6 & 17.5 & 47.4 & 31.2 & 23.9 & 2.9 & 11.6 & 13.1 \\
\hline Czech Republic & 33 & 22.3 & 19.8 & 15.5 & 30.7 & 21.1 & 23.6 & 1.4 & 8.8 & 12.2 \\
\hline Denmark & 38 & 37.0 & 15.2 & 38.4 & 56.0 & 45.7 & 28.0 & 3.9 & 1.9 & 31.2 \\
\hline Estonia & 2 & 10.0 & 0.0 & 16.2 & 14.8 & 9.8 & 10.3 & 0 & 10.0 & 0 \\
\hline Finland & 83 & 92.4 & 79.3 & 93.8 & 103.0 & 102.5 & 81.9 & 1.1 & 10.0 & 81.3 \\
\hline France & 401 & 34.1 & 15.5 & 29.3 & 57.9 & 41.7 & 26.1 & 5.0 & 2.3 & 26.4 \\
\hline FYR of Macedonia & 7 & 18.3 & 0.0 & 16.1 & 34.6 & 25.4 & 10.8 & 0 & 18.3 & 0 \\
\hline Greece & 46 & 28.8 & 9.3 & 33.1 & 43.9 & 34.0 & 23.2 & 5.6 & 10.0 & 13.1 \\
\hline Hungary $^{a}$ & 37 & 28.3 & 7.2 & 21.7 & 52.5 & 38.8 & 17.3 & 1.5 & 3.1 & 23.7 \\
\hline Iceland & 2 & 30.5 & 0.0 & 94.1 & 0.0 & 0.0 & 62.1 & 0 & 0 & 30.5 \\
\hline Italy $^{\mathrm{b}}$ & 247 & 29.6 & 18.2 & 31.8 & 38.7 & 33.8 & 25.1 & 2.6 & 7.7 & na \\
\hline Latvia $^{c}$ & 2 & 6.3 & 0.0 & 10.5 & 8.9 & 6.2 & 6.5 & 0 & 6.3 & 0 \\
\hline Lithuania & 17 & 32.2 & 19.7 & 23.8 & 48.2 & 44.4 & 19.4 & 11.4 & 9.5 & 11.4 \\
\hline Montenegro & 1 & 8.1 & 0.0 & 24.7 & 0.0 & 15.7 & 0.0 & 0 & 0 & 8.1 \\
\hline The Netherlands & 131 & 44.4 & 18.8 & 45.6 & 68.2 & 52.4 & 36.1 & 7.8 & 6.4 & 30.2 \\
\hline Norway & 42 & 46.3 & 24.0 & 39.9 & 73.2 & 56.0 & 36.2 & 1.1 & 0 & 45.2 \\
\hline Poland & 230 & 38.6 & 22.7 & 38.7 & 51.2 & 45.2 & 29.3 & 6.5 & 18.6 & 12.4 \\
\hline Portugal $^{\mathrm{c}}$ & 64 & 39.2 & 22.1 & 45.5 & 49.9 & 47.7 & 30.2 & 1.2 & 19.6 & 18.4 \\
\hline Romania & 35 & 10.6 & 1.9 & 7.3 & 21.9 & 8.9 & 12.4 & 5.8 & 4.2 & 0.6 \\
\hline Russia $^{a}$ & 168 & 16.1 & 5.5 & 14.0 & 29.1 & 16.3 & 15.9 & 5.5 & 3.7 & 6.6 \\
\hline Serbia & 28 & 24.5 & 5.4 & 27.4 & 39.5 & 32.4 & 16.2 & 6.1 & 1.8 & 16.6 \\
\hline Slovakia & 23 & 26.7 & 7.6 & 25.8 & 43.1 & 27.2 & 26.2 & 4.6 & 11.6 & 10.5 \\
\hline Slovenia & 6 & 21.3 & 10.9 & 33.0 & 20.4 & 27.7 & 14.6 & 7.1 & 10.7 & 3.6 \\
\hline Spain, Andalusia & 41 & 31.1 & 6.8 & 25.7 & 60.4 & 33.9 & 28.2 & 1.5 & 2.3 & 27.3 \\
\hline Spain, Aragon & 6 & 35.2 & 34.0 & 17.9 & 53.8 & 45.6 & 24.2 & 0 & 0 & 35.2 \\
\hline Spain, Basque & 26 & 95.7 & 20.0 & 134.0 & 145.5 & 100.3 & 90.8 & 3.7 & 7.4 & 84.6 \\
\hline Spain, Catalonia & 48 & 45.8 & 31.0 & 46.9 & 62.7 & 55.6 & 35.4 & 5.7 & 1.9 & 38.2 \\
\hline Spain, Valencia & 29 & 41.0 & 32.8 & 34.6 & 55.9 & 54.9 & 26.2 & 7.1 & 4.2 & 29.7 \\
\hline Sweden & 75 & 48.5 & 30.8 & 44.5 & 68.5 & 55.5 & 41.2 & 1.3 & 5.2 & 42.1 \\
\hline United Kingdom & 552 & 51.5 & 23.1 & 46.7 & 83.4 & 60.8 & 41.1 & 6.8 & 11.8 & 24.0 \\
\hline Total & 2512 & 33.6 & 16.4 & 32.2 & 51.5 & 39.2 & 27.5 & 4.8 & 7.4 & $20.1^{\mathrm{e}}$ \\
\hline
\end{tabular}

$H D$ haemodialysis, $P D$ peritoneal dialysis, $T x$ transplantation

${ }^{a}$ Assuming $86 \%$ coverage of the general population for Hungary, 50\% for Russia

${ }^{\mathrm{b}}$ Pre-emptive transplantation not included

${ }^{\mathrm{c}}$ Only patients from paediatric centres included

${ }^{\mathrm{d}}$ Patients with unknown treatment modalities excluded

${ }^{\mathrm{e}}$ Patients from Italy excluded 
the adolescent age group. More than half of the patients had a functioning kidney allograft (20.1 pmarp), whereas 7.4 patients pmarp were on peritoneal dialysis and 4.8 on haemodialysis. Treatment modality was unknown in 1.4 patients pmarp (Table 2).

\section{Conclusions}

The data contributed by 32 registries from 28 European countries by the end of 2007 allowed us to calculate current demographic figures for paediatric RRT across the continent. Both incidence and prevalence of RRT are about 20 times lower in children compared with adults [3]. In comparison to the last demographic report of the former EDTA registry 14 years ago [4], we found nearly threefold higher incidence and prevalence of RRT among children aged younger than 15 years. This difference is likely to be due to the critical underreporting to the previous registry based on questionnaire collection from individual centres. However, it may in some part also reflect a recent achievement of RRT programmes for all children in many countries and an increasing acceptance and survival of infants and children with multiple comorbidities in paediatric RRT programmes, resulting in a truly increased incidence and prevalence of RRT. Nevertheless, information extracted from the report on paediatric RRT of the current ERA-EDTA registry [5], which comprised data collected in 2000 from 11 western European countries, showed that children younger than 15 years had a very similar incidence and slightly higher prevalence compared with data presented in this report.
Disclosures No financial support was obtained from any institution or company except for logistic support from the authors' affiliation departments. The ESPN/ERA-EDTA registry is funded by the European Society of Paediatric Nephrology (ESPN), the European Renal Association (ERA-EDTA) and the NephroQUEST project. The NephroQUEST project has received funding from the European Union in the framework of the Public Health Programme (project number 2006114). Furthermore, Amgen has provided an unrestricted educational grant to assist the ESPN in the financial support of the registry.

\section{Conflict of interest None}

Open Access This article is distributed under the terms of the Creative Commons Attribution Noncommercial License which permits any noncommercial use, distribution, and reproduction in any medium, provided the original author(s) and source are credited.

\section{References}

1. Tizard EJ, Verrina E, van Stralen KJ, Jager KJ (2009) Progress with the European Society for Paediatric Nephrology (ESPN)/ERAEDTA Registry for children with established renal failure (ERF). Nephrol Dial Transplant 24:2615-2617

2. Jager KJ, Zoccali C, Kramar R, Dekker FW (2007) Measuring disease occurrence. Kidney Int 72:412-415

3. Stel VS, Kramer A, Zoccali C, Jager KJ (2009) The 2007 ERAEDTA registry annual report-a precis. NDT Plus 2:514-521

4. Mehls O, Rigden S, Ehrich JH, Berthoux F, Jones EH, Valderrabano F (1996) Report on management of renal failure in Europe, XXV, 1994. The child-adult interface. The EDTA-ERA Registry. European Dialysis and Transplant Association-European Renal Association. Nephrol Dial Transplant 11(Suppl 1):22-36

5. van der Heijden BJ, van Dijk PC, Verrier-Jones K, Jager KJ, Briggs JD (2004) Renal replacement therapy in children: data from 12 registries in Europe. Pediatr Nephrol 19:213-221 